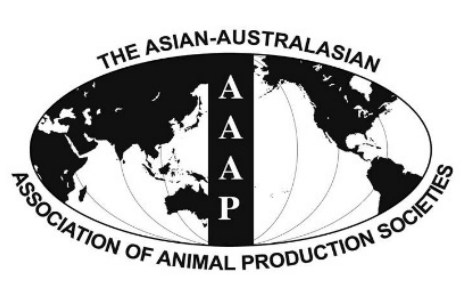

Open Access

Asian Australas. J. Anim. Sci.

Vol. 28, No. 9 : 1281-1287 September 2015

http://dx.doi.org/10.5713/ajas.15.0122

www.ajas.info

pISSN 1011-2367 elSSN 1976-5517

\title{
The Effect of Oregano and Cinnamon Essential Oils on Fermentation Quality and Aerobic Stability of Field Pea Silages
}

\author{
Sibel Soycan-Önenç*, Fisun Koc, Levent Coşkuntuna, M. Levent Özdüven, and Tuncay Gümüş ${ }^{1}$ \\ Animal Science Department, Agriculture Faculty, Namık Kemal University, Tekirdağ 59030, Turkey
}

\begin{abstract}
This study was performed to determine the effect of field pea silages which were the organic acid (OA) alternative of oregano and cinnamon essential oils on fermentation quality and aerobic stability. Whole crop pea was harvested at full pod stage and wilted in the laboratory at the $48 \mathrm{~h}$. The chopped pea was mixed and divided into equal portions allocated to five groups: CON (nontreated), distilled water, denoted as control group; OA group, a mixture of $60 \%$ formic acid, $20 \%$ sodium formate and $20 \%$ water applied at a rate of $5 \mathrm{~g} / \mathrm{kg}$ fresh forage (Silofarm Liquid, Farmavet); origanum (ORE) group, Origanum onites essential oil at $400 \mathrm{mg} / \mathrm{kg}$ fresh forage; cinnamon (CIN) group, cinnamon essential oil at $400 \mathrm{mg} / \mathrm{kg}$ fresh forage; origanum+cinnamon (ORECIN) group, a mixture of ORE and CIN applied at an equal rate of $400 \mathrm{mg} / \mathrm{kg}$ fresh forage. Cinnamon decreased acetic acid (AA), ammonia nitrogen $\left(\mathrm{NH}_{3}-\mathrm{N}\right)$ and weight loss (WL) at the end of 60 days silage. Crude protein (CP) and dry matter (DM) increased by cinnamon essential oil. Yeasts were not detected in any treatments, including the control, after 7 days of air exposure. The $\mathrm{CO}_{2}$ amount decreased and the formation mold was inhibited in the aerobic period by the addition of cinnamon oil. Oregano did not show a similar effect, but when it was used with cinnamon, it showed synergic effect on AA and during aerobic period, it showed antagonistic effect on mold formation and DM losses. It was found in this study that cinnamon can be an alternative to organic acids. (Key Words: Field Pea, Silage Additives, Essential Oil, Silage Quality)
\end{abstract}

\section{INTRODUCTION}

Legumes are used for forage, silage, food, ornament, soil improvement, polen, nectar resources, and grasslands. Among plant species, annual forage legumes are considered as the major source of nutritients for livestock and are grown worldwide (Ateş et al., 2010). They are a very important feed source for ruminants and can be used as hay, silage or grazing (Fernandes et al., 2013). The acreage of fodder pea (pisum arvense L.) and other forage legumes continues to increase in the Thrace region, Turkey and the world. The new fodder pea cultivars (cv Ateş, cv. Tore etc.) were widely adapted in Thrace region as high-quality annual forages (Arslan et al., 2012).

Field pea is one of forages that is difficult to ensilage

\footnotetext{
* Corresponding Author: Sibel Soycan-Önenç. Tel: +90-282-250-

2186, Fax:+90-282-250-9929, E-mail: ssonenc@nku.edu.tr

${ }^{1}$ Food Engineering Department, Agriculture Faculty, Namık Kemal University, Tekirdağ 59030, Turkey.

Submitted Feb. 10, 2015; Revised Apr. 16, 2015; Accepted May 19, 2015
}

and silage additives must be used during ensilage. Many biological and chemical additives have been developed to be used in silage fermentation (Kurtoğlu, 2011). Additives with protective properties based on organic acids have been used to prevent yeast and mold growth in silage and to increase aerobic stability (Henderson, 1993). Organic acids, especially formic acids show antibacterial effect because of the selective bactericidal effects of hydrogen ion concentration and undissolved acids in their structure (Henderson, 1993).

In recent years the usage of aromatic plants and their products in many areas (food, animal breeding, medicine) has increased because of their antibacterial, antifungal, antioxidant effects. The so called essential oil plants have an important place among the medicinal plants. In particular, the countries having coasts adjacent to the Mediterranean Sea are rich in essential oil plants (Ceylan, 1996). Because of the their antimicrobial effects, essential oils obtained from aromatic plants were shown to be useful in animal nutrition (Soycan-Önenç, 2008). However, defining their 
effects on silage fermentation is rather a new subject. Even though many plants extracts were reported to have antimicrobial activity (Burt, 2004), there is limited research reported about their usage as silage additives.

Therefore, this study was performed to determine the effects of oregano and cinnamon essential oils on fermentation quality and aerobic stability of field pea silages as an organic acid alternative.

\section{MATERIALS AND METHODS}

\section{Experimental treatments and silage preparation}

Whole crop pea was harvested at full pod stage and wilted in the laboratory at the $48 \mathrm{~h}$. After the wilting period it was chopped into pieces about 1.5 to $2.0 \mathrm{~cm}$. The chopped pea was mixed and divided into equal portions allocated to five groups: CON (non-treated), distilled water, denoted as control group; organic acid (OA) group, a mixture of $60 \%$ formic acid, $20 \%$ sodium formate and $20 \%$ water applied at a rate of $5 \mathrm{~g} / \mathrm{kg}$ fresh forage (Silofarm Liquid, Farmavet, Istanbul, Turkey); origanum (ORE) group, origanum onites essential oil at $400 \mathrm{mg} / \mathrm{kg}$ fresh forage; cinnamon (CIN) group, cinnamon essential oil at $400 \mathrm{mg} / \mathrm{kg}$ fresh forage; origanum+cinnamon (ORECIN) group, a mixture of ORE and CIN applied at an equal rate of $400 \mathrm{mg} / \mathrm{kg}$ fresh forage. Origanum and cinnamon essential oils were obtained from Ege Lokman Plant Botanic Company (Manisa, Turkey). The herbs used for steam-distilled essential oils are characterized in Table 1.

The application rate of ORE and CIN was determined by our earlier study, while OA was added as recommend by the manufacturer. On the day of the experiment, organic acid and essential oils were blended in $10 \mathrm{~mL}$ of distilled water and the whole mixture was sprayed over $6 \mathrm{~kg}$ (wet weight) of the chopped forage spread over a $4 \mathrm{~m}^{2}$ area. All organic acid and essential oils were applied to the forages in

Table 1. The chemical composition of essential oils

\begin{tabular}{lc}
\hline Compounds & Value \\
\hline Oregano & \\
Carvacrol & 59.03 \\
Thymol & 12.04 \\
Para cymen & 6.37 \\
$\Gamma$ - Terpinen & 3.86 \\
Another & 18.32 \\
Unknown & 0.32 \\
Total & 100 \\
Cinnamon & \\
Cinnamaldehyde propilene glycol acetal & 41.50 \\
Cinnamaldehyde & 35.28 \\
Propilene glycol & 2.76 \\
Unknown & 19.66 \\
Total & 100 \\
\hline
\end{tabular}

a uniform manner with constant mixing. Silage materials were placed in approximately $2 \mathrm{~kg}$ plastic bags by pressing, unless vacuum was obtained by exhauster, and covered strictly with 6 to 8 fold of stretch-film. There were 15 bags, and they were stored at ambient temperature $\left(20^{\circ} \mathrm{C}\right.$ to $\left.25^{\circ} \mathrm{C}\right)$. Fresh and ensiled material (on days 60 after ensiled, three bags per treatment) were sampled for chemical and microbiological analysis. At the end of the ensiling period (opening day: 0 day), the silages were subjected to an aerobic stability test for 7 days in a system developed by Ashbell et al. (1991). In this system, the number of yeasts and molds, change in $\mathrm{pH}$ and amount of $\mathrm{CO}_{2}$ produced during the test are used as aerobic deterioration indicators.

\section{Chemical analysis}

The fresh and silage samples were dried at $60^{\circ} \mathrm{C}$ for 72 $\mathrm{h}$ in a fan-assisted oven. After drying, samples were ground through a $1 \mathrm{~mm}$ screen for chemical analysis. The dry matter (DM) was determined by drying the samples at $105^{\circ} \mathrm{C}$ for $16 \mathrm{~h}$. Organic matter, crude protein and ether extract contents of feed samples were determined according to the methods of AOAC (1990). The crude fibre content of the feed was determined by Naumann and Bassler (1993). Nitrogen-free extract (NFE), hemicellulase and cellulase was determined by calculation. Neutral detergent fibre (NDF), acid detergent fibre (ADF) and acid detergent lignin (ADL) content determined as described by Van Soest et al. (1991). Enzyme soluble organic matter (ESOM) was determined with the procedure reported by Naumann and Bassler (1993). In the technique, pre-treatment with pepsinhydrochloric acid solution was followed treatment by cellulase (Onozuka R 10 from Trichoderma viride, Merck, Darmstadt, Germany) .

Metabolisable energy (ME) content of the experimental feed was calculated based on the chemical composition (Anonymous, 1991), NDF (Kirchgessner et al., 1977), ADF (Kirchgessner and Kellner, 1981), ADL (Kirchgessner et al., 1977) and ESOM (Jeroch et al., 1999) by following equations:

$\mathrm{ME}, \mathrm{kcal} / \mathrm{kg}$ organic matter $(\mathrm{OM})$

$=3,260+\left(0.455 \times\right.$ crude protein $[\mathrm{CP}]^{*+3.51 \times \text { ether extract }}$ $\left.[\mathrm{EE}]^{*}\right)-4.037 \times$ crude fiber $(\mathrm{CF})^{*}$

$*$ in $\mathrm{OM} \mathrm{g} / \mathrm{kg}$

$$
\begin{aligned}
& \mathrm{ME}_{\mathrm{NDF}}, \mathrm{kcal} / \mathrm{kg} \mathrm{DM}=3381.9-19.98 \times \mathrm{NDF}^{*} \\
& * * \mathrm{ME}_{\mathrm{ADF}}, \mathrm{MJ} / \mathrm{kg} \mathrm{DM}=14.70-0.150 \times \mathrm{ADF}^{*} \\
& \mathrm{ME}_{\mathrm{ADL}}, \mathrm{kcal} / \mathrm{kg} \mathrm{DM}=2764.4-102.73 \times \mathrm{ADL}^{*} \\
& (* \mathrm{NDF}, \mathrm{ADF} \text {, and ADL in \%) }
\end{aligned}
$$

$$
\begin{aligned}
& * * \mathrm{ME}_{\mathrm{ESOM}}, \mathrm{MJ} / \mathrm{kg} \mathrm{DM}=0.54+0.001987 \mathrm{CP}^{*}+0.01537 \\
& \mathrm{ESOM}^{*+0.000706} \mathrm{EE}^{*} \times \mathrm{EE}^{*}-0.00001262 \mathrm{ESOM}^{*} \times \mathrm{crude} \\
& \text { ash }(\mathrm{CA})^{*-0}-00003517 \mathrm{ESOM}^{*} \times \mathrm{CP}^{*}
\end{aligned}
$$


(CP, EE, CA g/kg; ESOM in g/kg DM)

** ME contents were translated into kilocalories

Fermentation losses were evaluated according to weight loss (Filya, 2003). $\mathrm{pH}$ values and ammonia nitrogen $\left(\mathrm{NH}_{3}-\mathrm{N}\right)$ content of fresh and silage samples was determined, according to Anonymous (1986). The watersoluble carbohydrates (WSCs) content of silages was determined by spectrophotometer (Shimadzu UV-1201, Kyoto, Japan) after reaction with an antron reagent Anonymous (1986). Lactic acid (LA) and acetic acid (AA) were determined by the spectrophotometric method (Barker and Summerson, 1941).

Buffer capacity $(\mathrm{Bc})$ in a fresh material was determined by Playne and Mcdonald (1966). Fermentation efficiency in a fresh material was determined according to the following equation (Weissbach et al., 1974):

Fermentation efficiency (FE)

$=\mathrm{DM}(\%)+\mathrm{WSC}(\mathrm{g} / \mathrm{kg} \mathrm{DM}) / \mathrm{Bc}(\mathrm{Meq} \mathrm{NaOH} \mathrm{kg} / \mathrm{DM})$

In the present study, the chemical compositions of oregano and cinnamon essential oils were identified using gas chromatography-mass spectrometry (GC/MS) (HP 6890 GC/5973 MSD) at Ege University Center R\&D and Pharmacokinetic Applications-Environmental \& Food Analysis Laboratories-Food Control Laboratory (Bornova, Izmir, Turkey) according to the United States Pharmacopeia National Formularty.

\section{Microbiologic analysis}

LA bacteria (LAB), yeast and mold numbers were obtained according to the methods reported by Seale et al. (1990). The microbiological examination included enumeration of lactobacilli on pour plate Rogosa agar (Oxoid CM627 incubated at $30^{\circ} \mathrm{C}$ for 3 days), yeast and molds on spread plate malt extract agar (acidified with LA to $\mathrm{pH} 4.0$ and incubated at $30^{\circ} \mathrm{C}$ for 3 days). The lactobacilli mold and yeast numbers of the silages were converted into logarithmic coli form unit (cfu/g).

\section{Statistical analyses}

The data obtained were evaluated using the general linear model procedure of SPSS ver. 16 (SPSS Inc., Chicago, IL, USA). Duncan's test was employed for the comparison of the differences between the group averages (Efe et al., 2000).

\section{RESULTS}

Chemical composition of fresh and after ensiled field pea is given in Table 2. DM content of field pea before silage was $31.17 \%$ (after wilting period), CP was $23.37 \%$, WSC was $38.02 \mathrm{~g} / \mathrm{kg}$, DM and $\mathrm{Bc}$ was determined as $187.88 \mathrm{Meq} \mathrm{NaOH} \mathrm{kg} / \mathrm{DM}$ (Table 3). CF content is $22.20 \%$, structural carbohydrates composition of cell wall was $39.95 \%$ NDF, $25.08 \%$ ADF and $8.98 \%$ ADL (in DM). Adding ORE and CIN into the silages increased CP levels compared to $\mathrm{CON}(\mathrm{p}<0.01)$. While OA treatment decreased $\mathrm{CF}$ contents significantly $(\mathrm{p}<0.01)$ compared to the other groups, the ADL, hemicellulose and cellulose contents of OA group were not similarly affected.

While CF contents were found to be similar out of OA group, cell wall components were found to be affected by treatments and an increase was found in their NDF and $\mathrm{ADF}$ ratios comparing to $\mathrm{CON}(\mathrm{p}<0.01)$. ADL and hemicellulose ratios decreased with CIN treatment and thus an increase in cellulose ratio occurred $(\mathrm{p}<0.01)$.

When 4.31 to $4.58 \mathrm{pH}$ values were determined in silages, the highest DM contents were determined in OA $(26.65 \%)$ and CIN (25.49\%, Table 3). ORE treatment caused DM content to decrease $(22.64 \%)$. On the other hand the lowest weight loss occurred (1.24\%) in the CIN group, while the highest was $1.82 \%$ and occurred in ORECIN group $(\mathrm{p}<0.01)$. OA, ORE, CIN, and ORECIN addition affected fermentation parameters of pea silages.

However, AA levels in all groups decreased compared to CON Group $(\mathrm{p}<0.05), \mathrm{NH}_{3}-\mathrm{N}$ levels in treatment groups except ORE group decreased $(\mathrm{p}<0.01)$.

Enterobacteria and mold growth were not observed in pea silage at 0 day. $\mathrm{LAB}$ was not determined in $\mathrm{CON}$ silage, the highest $\mathrm{LAB}$ number was determined in $\mathrm{OA}$ and the

Table 2. Chemical composition of fresh pea and silage ensiled for 60 days (\% DM)

\begin{tabular}{lccccccccccc}
\hline Treatments & OM & CP & EE & CF & NFE & CA & NDF & ADF & ADL & Hemicellulose & Cellulose \\
\hline FF & 92.64 & 23.37 & 1.98 & 22.20 & 45.09 & 7.36 & 39.95 & 25.08 & 8.98 & 14.87 & 16.10 \\
CON & $92.22 \pm 0.01^{\mathrm{AB}}$ & $22.34 \pm 0.02^{\mathrm{c}}$ & $2.63 \pm 0.01^{\mathrm{b}}$ & $25.64 \pm 0.18^{\mathrm{a}}$ & $41.60 \pm 0.18^{\mathrm{c}}$ & $7.78 \pm 0.01^{\mathrm{AB}}$ & $37.56 \pm 0.06^{\mathrm{c}}$ & $27.52 \pm 0.16^{\mathrm{d}}$ & $7.89 \pm 0.09^{\mathrm{d}}$ & $10.05 \pm 0.21^{\mathrm{a}}$ & $19.62 \pm 0.25^{\mathrm{c}}$ \\
OA & $92.06 \pm 0.11^{\mathrm{B}}$ & $21.09 \pm 0.10^{\mathrm{e}}$ & $2.34 \pm 0.01^{\mathrm{d}}$ & $24.13 \pm 0.19^{\mathrm{b}}$ & $44.50 \pm 0.18^{\mathrm{a}}$ & $7.94 \pm 0.11^{\mathrm{A}}$ & $39.84 \pm 0.25^{\mathrm{a}}$ & $30.93 \pm 0.15^{\mathrm{a}}$ & $9.89 \pm 0.03^{\mathrm{b}}$ & $8.90 \pm 0.14^{\mathrm{b}}$ & $21.04 \pm 0.18^{\mathrm{b}}$ \\
ORE & $92.34 \pm 0.04^{\mathrm{A}}$ & $23.29 \pm 0.05^{\mathrm{b}}$ & $2.92 \pm 0.11^{\mathrm{a}}$ & $25.46 \pm 0.09^{\mathrm{a}}$ & $40.67 \pm 0.07^{\mathrm{d}}$ & $7.66 \pm 0.04^{\mathrm{B}}$ & $39.23 \pm 0.01^{\mathrm{b}}$ & $29.92 \pm 0.32^{\mathrm{b}}$ & $12.69 \pm 0.06^{\mathrm{a}}$ & $9.31 \pm 0.33^{\mathrm{b}}$ & $17.23 \pm 0.36^{\mathrm{d}}$ \\
CIN & $92.33 \pm 0.04^{\mathrm{A}}$ & $24.26 \pm 0.03^{\mathrm{a}}$ & $2.57 \pm 0.01^{\mathrm{c}}$ & $25.65 \pm 0.11^{\mathrm{a}}$ & $39.84 \pm 0.14^{\mathrm{c}}$ & $7.67 \pm 0.04^{\mathrm{B}}$ & $38.84 \pm 0.11^{\mathrm{b}}$ & $31.09 \pm 0.06^{\mathrm{a}}$ & $7.14 \pm 0.39^{\mathrm{c}}$ & $7.75 \pm 0.17^{\mathrm{c}}$ & $23.95 \pm 0.34^{\mathrm{a}}$ \\
ORECIN & $92.26 \pm 0.04^{\mathrm{A}}$ & $21.62 \pm 0.06^{\mathrm{d}}$ & $2.58 \pm 0.01^{\mathrm{c}}$ & $25.39 \pm 0.04^{\mathrm{a}}$ & $42.66 \pm 0.09^{\mathrm{b}}$ & $7.74 \pm 0.04^{\mathrm{B}}$ & $39.05 \pm 0.05^{\mathrm{b}}$ & $28.73 \pm 0.11^{\mathrm{c}}$ & $8.64 \pm 0.07^{\mathrm{C}}$ & $10.32 \pm 0.16^{\mathrm{a}}$ & $20.01 \pm 0.17^{\mathrm{C}}$ \\
p-value & 0.05 & 0.01 & 0.01 & 0.01 & 0.01 & 0.05 & 0.01 & 0.01 & 0.01 & 0.01 & 0.01 \\
\hline
\end{tabular}

$\overline{\mathrm{FF}}$, fresh field pea; CON, control; OA, organic acid; ORE, origanum; CIN, cinnamon; ORECIN, origanum+cinnamon; OM, organic matter; CP, crude protein; EE, ether extract; CF, crude fiber; NFE, non-frei nitrogen; CA, crude ash; NDF, neutral detergent fiber; ADF, acid detergent fiber; ADL, acid detergent lignin.

${ }^{A, B, C}$ Means with different letters in the same column are statistically significant $(\mathrm{p}<0.05)$.

${ }^{a, b, c}$ Means with different letters in the same column are statistically significant $(p<0.01)$. 
Table 3. Fermentation quality of field pea silage ensiled for 60 days

\begin{tabular}{lccccccc}
\hline Treatments & DM (\%) & pH & $\begin{array}{c}\text { WSC } \\
(\mathrm{g} / \mathrm{kg} \mathrm{DM})\end{array}$ & $\begin{array}{c}\mathrm{Bc} \\
(\mathrm{Meq} \mathrm{NaOH} \mathrm{kg} / \mathrm{DM})\end{array}$ & & & \\
\hline FF & 31.17 & 6.06 & 38.02 & 187.88 & & & \\
& & & & $\mathrm{LA}$ & $\mathrm{AA}$ & $\begin{array}{c}\mathrm{NH}_{3}-\mathrm{N} \\
(\mathrm{g} / \mathrm{kg} \mathrm{TN})\end{array}$ & $\begin{array}{c}\mathrm{WL} \\
(\%)\end{array}$ \\
CON & $23.53 \pm 0.09^{\mathrm{d}}$ & $4.31 \pm 0.01^{\mathrm{C}}$ & $11.53 \pm 0.06^{\mathrm{c}}$ & $56.66 \pm 4.12^{\mathrm{a}}$ & $23.82 \pm 1.73^{\mathrm{A}}$ & $99.48 \pm 0.35^{\mathrm{b}}$ & $1.52 \pm 0.05^{\mathrm{b}}$ \\
OA & $26.65 \pm 0.09^{\mathrm{a}}$ & $4.58 \pm 0.06^{\mathrm{A}}$ & $17.14 \pm 0.24^{\mathrm{a}}$ & $47.37 \pm 3.82^{\mathrm{b}}$ & $19.85 \pm 0.58^{\mathrm{B}}$ & $63.59 \pm 0.14^{\mathrm{d}}$ & $1.71 \pm 0.05^{\mathrm{ab}}$ \\
ORE & $22.64 \pm 0.06^{\mathrm{e}}$ & $4.40 \pm 0.03^{\mathrm{BC}}$ & $15.33 \pm 0.43^{\mathrm{b}}$ & $46.67 \pm 1.13^{\mathrm{b}}$ & $22.99 \pm 0.49^{\mathrm{A}}$ & $102.40 \pm 0.78^{\mathrm{a}}$ & $1.67 \pm 0.11^{\mathrm{ab}}$ \\
CIN & $25.49 \pm 0.11^{\mathrm{b}}$ & $4.47 \pm 0.01^{\mathrm{B}}$ & $9.39 \pm 0.24^{\mathrm{d}}$ & $26.02 \pm 2.28^{\mathrm{c}}$ & $19.36 \pm 0.66^{\mathrm{B}}$ & $40.90 \pm 0.42^{\mathrm{e}}$ & $1.24 \pm 0.04^{\mathrm{c}}$ \\
ORECIN & $23.99 \pm 0.08^{\mathrm{c}}$ & $4.45 \pm 0.01^{\mathrm{B}}$ & $12.07 \pm 0.24^{\mathrm{c}}$ & $30.36 \pm 1.93^{\mathrm{c}}$ & $17.24 \pm 0.52^{\mathrm{B}}$ & $68.21 \pm 0.98^{\mathrm{c}}$ & $1.82 \pm 0.05^{\mathrm{a}}$ \\
p-value & 0.01 & 0.05 & 0.01 & 0.01 & 0.05 & 0.01 & 0.01 \\
\hline
\end{tabular}

FF, fresh field pea; CON, control; OA, organic acid; ORE, origanum; CIN, cinnamon; ORECIN, origanum+cinnamon; LA, lactic acid; AA, acetic acid; $\mathrm{NH}_{3}-\mathrm{N}$, ammonia nitrogen; WL, weight loss; DM, dry matter; WSC, water-soluble carbohydrates; Bc, buffer capacity; TN, Total nitrogen.

$\mathrm{A}, \mathrm{B}, \mathrm{C}$ Means with different letters in the same column are statistically significant $(\mathrm{p}<0.05)$.

${ }^{a, b, c}$ Means with different letters in the same column are statistically significant $(p<0.01)$.

lowest was found in ORE in Table $4(\mathrm{p}<0.01)$. The amount of yeast at 0 day was not determined in OA group but the number of yeast was determined to be the highest in CIN as $2.52 \log _{10} \mathrm{cfu} / \mathrm{g}$.

The results of the aerobic exposure test are given in Table 4. It was observed at the end of aerobic period (7 day) that there was an significant increase in $\mathrm{pH}$ and a decreased amount of $\mathrm{CO}_{2}$ in treatments compared to $\mathrm{CON}(\mathrm{p}<0.01)$. Similarly, a decrease occurred in mold numbers in OA, ORE and CIN treatments. DM amount was found to be higher in OA, CIN ORE, and ORECIN additives compared to $\mathrm{CON}$ silages $(\mathrm{p}<0.01)$. Based on temperature, the silage that exhibited signs of aerobic deterioration included those treated with CIN as well as CON (Figure 1). This was evident by the elevation of temperature by more than $2^{\circ} \mathrm{C}$ over ambient temperature. These treatments also exhibited the highest silage $\mathrm{pH}$ after 7 days of aerobic exposure.

Adding OA, ORE, CIN, and ORECIN into the field pea silage decreased ESOM amount (Table 5). This decrease was found to be statistically significant in silages where CIN was added $(p<0.05)$. The ME content of ORECIN group calculated with the ESOM amounts were found to be higher numerically than the control group. The results of ME calculated according to OM, NDF, ADF, and ADL are shown in Table 5.

\section{DISCUSSION}

Generally with the increase of DM level of silage products, $\mathrm{pH}$ value, which is needed for silage stability,

Table 4. Effects of organic acid, oregano and cinnamon essential oils on overall composition of pea silages after 7 days of aerobic exposure and on microbial counts

\begin{tabular}{|c|c|c|c|c|c|c|}
\hline Treatments & $\% \mathrm{DM}$ & $\mathrm{pH}$ & $\begin{array}{c}\text { Enterobacter } \\
\left(\log _{10} \mathrm{cfu} / \mathrm{g}\right)\end{array}$ & $\begin{array}{l}\text { Lactobacilli } \\
\left(\log _{10} \mathrm{cfu} / \mathrm{g}\right)\end{array}$ & $\begin{array}{c}\text { Yeast } \\
\left(\log _{10} \mathrm{cfu} / \mathrm{g}\right)\end{array}$ & $\begin{array}{c}\text { Mould } \\
\left(\log _{10} \mathrm{cfu} / \mathrm{g}\right)\end{array}$ \\
\hline \multicolumn{7}{|l|}{0 day } \\
\hline $\mathrm{CON}$ & $23.53 \pm 0.09^{\mathrm{d}}$ & $4.31 \pm 0.01^{\mathrm{C}}$ & ND & ND & $0.33 \pm 0.33^{\mathrm{c}}$ & ND \\
\hline $\mathrm{OA}$ & $26.65 \pm 0.09^{\mathrm{a}}$ & $4.58 \pm 0.06^{\mathrm{A}}$ & ND & $2.42 \pm 0.02^{\mathrm{a}}$ & ND & ND \\
\hline ORE & $22.64 \pm 0.06^{\mathrm{e}}$ & $4.40 \pm 0.03^{\mathrm{BC}}$ & ND & $2.17 \pm 0.07^{\mathrm{b}}$ & $1.60 \pm 0.23^{\mathrm{b}}$ & ND \\
\hline $\mathrm{CIN}$ & $25.49 \pm 0.11^{\mathrm{b}}$ & $4.47 \pm 0.01^{\mathrm{B}}$ & ND & $2.23 \pm 0.01^{\mathrm{ab}}$ & $2.52 \pm 0.14^{\mathrm{a}}$ & ND \\
\hline ORECIN & $23.99 \pm 0.08^{\mathrm{c}}$ & $4.45 \pm 0.01^{\mathrm{B}}$ & ND & $2.24 \pm 0.13^{\mathrm{ab}}$ & $2.17 \pm 0.06^{\mathrm{ab}}$ & ND \\
\hline $\mathrm{p}$-value & 0.001 & 0.05 & - & 0.001 & 0.001 & \\
\hline Treatments & $\% \mathrm{DM}$ & $\mathrm{pH}$ & $\begin{array}{l}\text { Enterobacter } \\
\left(\log _{10} \mathrm{cfu} / \mathrm{g}\right)\end{array}$ & $\mathrm{CO}_{2}(\mathrm{~g} / \mathrm{kg} \mathrm{DM})$ & $\begin{array}{c}\text { Yeast } \\
\left(\log _{10} \mathrm{cfu} / \mathrm{g}\right)\end{array}$ & $\begin{array}{c}\text { Mould } \\
\left(\log _{10} \mathrm{cfu} / \mathrm{g}\right)\end{array}$ \\
\hline \multicolumn{7}{|l|}{7 day } \\
\hline $\mathrm{CON}$ & $19.69 \pm 0.12^{\mathrm{d}}$ & $8.02 \pm 0.11^{\mathrm{c}}$ & ND & $115.94 \pm 0.44^{\mathrm{a}}$ & ND & $2.76 \pm 0.01^{\mathrm{a}}$ \\
\hline $\mathrm{OA}$ & $23.42 \pm 0.10^{\mathrm{a}}$ & $8.76 \pm 0.02^{\mathrm{a}}$ & ND & $73.97 \pm 0.24^{\mathrm{b}}$ & ND & $2.07 \pm 0.03^{\mathrm{c}}$ \\
\hline ORE & $19.70 \pm 0.01^{\mathrm{d}}$ & $8.61 \pm 0.01^{\mathrm{ab}}$ & ND & $64.52 \pm 0.16^{\mathrm{c}}$ & ND & $2.10 \pm 0.01^{\mathrm{c}}$ \\
\hline $\mathrm{CIN}$ & $21.43 \pm 0.14^{\mathrm{c}}$ & $8.77 \pm 0.02^{\mathrm{a}}$ & ND & $19.33 \pm 0.08^{\mathrm{e}}$ & ND & $2.28 \pm 0.03^{\mathrm{b}}$ \\
\hline ORECIN & $22.25 \pm 0.10^{\mathrm{b}}$ & $8.53 \pm 0.04^{b}$ & ND & $26.41 \pm 0.089^{d}$ & ND & $2.74 \pm 0.04^{\mathrm{a}}$ \\
\hline p-value & 0.001 & 0.001 & - & 0.001 & - & 0.001 \\
\hline
\end{tabular}

DM, dry matter; CON, control; OA, organic acid; ORE, origanum; CIN, cinnamon; ORECIN, origanum+cinnamon; ND, not determined.

${ }^{\mathrm{ABC}}$ Means with different letters in the same column are statistically significant $(\mathrm{p}<0.05)$.

${ }^{a, b, c}$ Means with different letters in the same column are statistically significant $(p<0.01)$. 


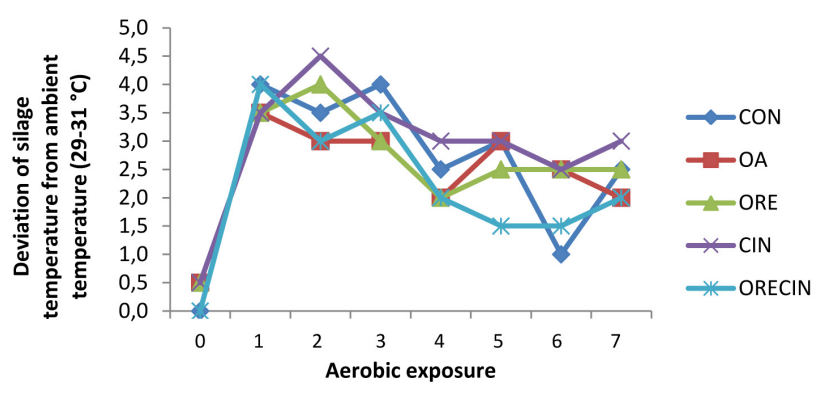

Figure 1. Deviation of silage temperature from ambient temperature $\left(29^{\circ} \mathrm{C}-31^{\circ} \mathrm{C}\right)$ during 7 days of aerobic exposure. CON, control; OA, organic acid; ORE, origanum; CIN, cinnamon; ORECIN, origanum+cinnamon.

increases and water activity falls. This shows the necessity of the application of a fading process before silaging products with high water content to achieve good silage fermentation (Filya, 2000). In this study, DM content reached $31.17 \%$ with fading, field pea fermentation possibility activity becomes $31.79 \%$. However, while FE values in well-fermented silage should be higher than 45, there is a risk of the silage becoming anaerobically unstable (Weissbach et al., 1974). Other than, DM, WSC, and Bc are also important factors effecting FE value. These values in the study material were found as $38.02 \mathrm{~g} / \mathrm{kg}$ and 187.88 Meq $\mathrm{NaOH} \mathrm{kg} / \mathrm{DM}$, respectively. In order to obtain stable silage, OA, ORE, and CIN essential oils were added.

Rondahl et al. (2011) determined DM, CA, CP, WSC, and $\mathrm{Bc}$ values when Pisum sativum ssp. arvense $\mathrm{L}$. was harvested in five different vegetation periods as 127 to 167 $\mathrm{g} / \mathrm{kg} \mathrm{DM}, 67$ to $130 \mathrm{~g} / \mathrm{kg} \mathrm{DM}, 232$ to $245 \mathrm{~g} / \mathrm{kg} \mathrm{DM}, 55$ to $140 \mathrm{~g} / \mathrm{kg} \mathrm{DM}, 328$ to $409 \mathrm{Meq} \mathrm{NaOH} \mathrm{kg} / \mathrm{DM}$, respectively. After wilting was applied, these values were reported to change to 423 to $488 \mathrm{~g} / \mathrm{kg} \mathrm{KM}, 64$ to $99 \mathrm{~g} / \mathrm{kg} \mathrm{DM}, 253$ to $280 \mathrm{~g} / \mathrm{kg}$ DM, $40131 \mathrm{~g} / \mathrm{kg} \mathrm{DM}, 252$ to $357 \mathrm{Meq} \mathrm{NaOH}$ $\mathrm{kg} / \mathrm{DM}$. Our results were lower than Rondahl et al. (2011) except CA. Ateş et al. (2010) determined CP, NDF, and ADF contents from his study of Pisum arvense. as $15.13 \%$, $42.69 \%$, and $31.42 \%$, respectively. Arslan et al. (2012) found $\mathrm{CF}, \mathrm{NDF}$, and $\mathrm{ADF}$ contents in the same type of forage as $23.10 \%, 36.11 \%$, and $29.10 \%$ level. HP content of field pea used in the study is higher than that reported by Ateş et al. (2010) and lower than their NDF and ADF contents. CF content is also lower than Arslan et al. (2012) but similar with NDF and ADF contents.

While 3.5 to $4.0 \mathrm{pH}$ is expected in a good quality silage, 4.0 to $5.0 \mathrm{pH}$ is widespread in legume silages. Rondahl et al. (2011) added formic and propionic acid in 2/1 rate into the field peas harvested in different periods and reported that $\mathrm{pH}$ varied between 3.8 to 4.7 in silos opened at the end of 102 days of silage. Our results were between the values reported by Rondahl et al. (2011) as 4.31 to 4.58 .

High LA production in silos reduces $\mathrm{pH}$ and restricts the proteolytic activity (Nadeau et al., 2000). Therefore, for silage materials not to deteriorate, the medium must contain LAB and enough WSC for them to produce LA. LAB can only produce LA required for silage fermentation when enough WSC is present (Filya, 2000). In this study, LAB was not determined in CON silage, while it was determined to be between $2.42 \log _{10} \mathrm{cfu} / \mathrm{g}(\mathrm{OA})$ and $2.17 \log _{10} \mathrm{cfu} / \mathrm{g}$ (ORE) in the treated groups. Since there was enough LAB in the environment at the beginning of fermentation in $\mathrm{CON}$, WSC was converted to LA but the ammonia $\left(\mathrm{NH}_{3}-\mathrm{N}: 99.48\right.$ $\mathrm{g} / \mathrm{kg}$ DM TN) in the environment inhibits LAB depending on the increase in $\mathrm{pH}$ or wilting applied to field pea might. Kurtoğlu (2011) reported that different effects of wilting was caused by the epiphytic microorganisms density. Wilting effects clostridial activity in some silages while not in others, and while it reduces LAB activities in some silages, osmotolerant (partially resistant) LAB population stayed active and silage fermentation was restricted in the present case. The increase in LA and AA in CON group might be caused by the decrease in NDF and ADF (Table 2). In addition, low pH (CON 4.31) was reported to open cell wall fractions by increasing acid hydrolysis of hemicelluloses (Bolsen et al., 1996). When cell walls were examined in Table 2, it appeared that ORE addition into silage increased NDF, ADF, and ADL, which reduced NFE, hemicellulose and cellulose. On the other hand, CIN addition into silage increased NDF, ADF, and cellulose

Table 5. ESOM and ME contents of pea silages

\begin{tabular}{lcccccc}
\hline Treatments & $\mathrm{ESOM}^{(\% \mathrm{DM})}$ & $\mathrm{ME}_{\mathrm{ESOM}}{ }^{1}$ & $\mathrm{ME}_{\mathrm{OM}}{ }^{1}$ & $\mathrm{ME}_{\mathrm{NDF}}{ }^{\mathrm{l}}$ & $\mathrm{ME}_{\mathrm{ADF}}{ }^{\mathrm{a}}$ & $\mathrm{ME}_{\mathrm{ADL}}{ }^{\mathrm{a}}$ \\
\hline CON & $68.51 \pm 0.11^{\mathrm{A}}$ & $1,422 \pm 3.56^{\mathrm{a}}$ & $2,165 \pm 7.23^{\mathrm{b}}$ & $2,631 \pm 1.17^{\mathrm{a}}$ & $2,527 \pm 5.60^{\mathrm{a}}$ & $1,954 \pm 9.44^{\mathrm{b}}$ \\
OA & $67.12 \pm 0.34^{\mathrm{B}}$ & $1,436 \pm 3.30^{\mathrm{a}}$ & $2,205 \pm 3.71^{\mathrm{a}}$ & $2,586 \pm 4.95^{\mathrm{c}}$ & $2,405 \pm 5.30^{\mathrm{d}}$ & $1,748 \pm 2.95^{\mathrm{d}}$ \\
ORE & $67.73 \pm 0.25^{\mathrm{AB}}$ & $1,389 \pm 5.78^{\mathrm{b}}$ & $2,191 \pm 3.51^{\mathrm{a}}$ & $2,598 \pm 0.23^{\mathrm{b}}$ & $2,440 \pm 11.36^{\mathrm{c}}$ & $1,461 \pm 5.87^{\mathrm{e}}$ \\
CIN & $65.81 \pm 0.67^{\mathrm{C}}$ & $1,279 \pm 7.91^{\mathrm{c}}$ & $2,175 \pm 4.61^{\mathrm{b}}$ & $2,606 \pm 2.22^{\mathrm{b}}$ & $2,399 \pm 2.16^{\mathrm{d}}$ & $2,031 \pm 39.62^{\mathrm{a}}$ \\
ORECIN & $67.25 \pm 0.32^{\mathrm{AB}}$ & $1,436 \pm 6.00^{\mathrm{a}}$ & $2,172 \pm 1.12^{\mathrm{b}}$ & $2,602 \pm 1.07^{\mathrm{b}}$ & $2,484 \pm 3.86^{\mathrm{b}}$ & $1,877 \pm 7.00^{\mathrm{c}}$ \\
p-value & 0.05 & 0.01 & 0.01 & 0.01 & 0.01 & 0.01 \\
\hline
\end{tabular}

ESOM, enzyme soluble organic matter; ME, metabolisable energy; CON, control; OA, organic acid; ORE, origanum; CIN, cinnamon; ORECIN, origanum+cinnamon.

${ }^{1} \mathrm{Kcal} / \mathrm{kg}$ DM.

${ }^{a, b, c}$ Means with different letters in the same column are statistically significant $(\mathrm{p}<0.01)$.

${ }^{A, B, C}$ Means with different letters in the same column are statistically significant $(\mathrm{p}<0.05)$. 
amounts but it decreased NFE, ADL and hemicellulose $(p<0.01$ and $p<0.05)$. When it was compared with ORE silage, the reduction of ADL content in ORECIN silage and increase in NFE were remarkable.

Low LA, AA, and $\mathrm{NH}_{3}-\mathrm{N}$ amounts occurred in field pea silage to which $\mathrm{CIN}$ was added, however, a low $\mathrm{NH}_{3}-\mathrm{N}$ value did not occur in ORE added silage. Decreased values of $\mathrm{LA}, \mathrm{AA}$ and $\mathrm{NH}_{3}-\mathrm{N}$ in ORECIN silage was caused by the addition of CIN essential oil. Silage additives containing OA were reported to prevent proteolysis in silages by repressing the heating of the silage (McDonald et al., 1991). CIN might inhibit proteolysis by showing a similar effect as OA. As can be seen in Table 2, CP content was determined as $24.26 \%$ in CIN silage and was the highest among all the silages, which support the evidence of McDonald et al. (1991). In addition, despite $\mathrm{NH}_{3}-\mathrm{N}$ being low in ORECIN silage, a decreasing in $\mathrm{CP}$ was caused by DM loss. In fact, CIN addition is effective in preventing DM loss and in decreasing WL significantly comparing to the other treatments.

Enterobacteria and mold could not be determined in all groups when the silages were opened. While no yeast was found in the OA group during this period, an increase was seen in ORE, CIN, and ORECIN groups compared to CON. Yeast was not found in all groups at the end of the aerobic period. This was due to the medium, which was acidic at the beginning $(\mathrm{pH}=4.31-4.58)$ and became basic $(\mathrm{pH}=$ 8.02-8.77) at the end of the aerobic period. In fact, acidophilic yeast was reported not to have resistance to low pHs. In previous studies, antimicrobial effects of essential oils was reported to show variations from acidic $\mathrm{pH}$ to basic $\mathrm{pH}$ depending on whether microorganisms present were acidophilic or basophilic (Nguefack et al., 2009). In our study, ORE, CIN, and ORECIN showed an increasing effect in low pHs (during the ensilage period).

While adding OA, ORE, and CIN into field pea silages reduced mold growth significantly during the aerobic period, no similar decrease was observed in ORECIN group. This may be associated with the existing antagonistic effect between carvacrol and cinnamaldehyde. A high proportion in the essential oil of oregano and cinnamon used in the study consist of carvacrol and cinnamaldehyde.

Organic acids, especially formic acid, show antibacterial effects due to the selective bactericidal action of unsolved acid and hydrogen ion concentration in their structures (Henderson, 1993). Purified compounds derived from essential oils, such as carvacrol, eugenol, linalool, cinnamic aldehyde and thymol were able to inhibit a wide variety of microorganisms (Gallucci et al., 2009). The antimicrobial impact of cinnamaldehyde (a non-phenolic phenylpropene and main active compound of cinnamon) in suggested to arise through its carbonyl group interaction with proteins in the periplasm and inactivation microbial enzymes (Burt, 2004).

Cinnamon essential oil used in the study contained $41.5 \%$ cinnamaldehyde propylene glycol acetal and 35.28\% cinnamaldehyde (Table 1) and their phenylpropanoid was determined as the cause of the antimicrobial effect. However, even though 59.03\% carvacrol and $12.04 \%$ thymol were in oregano essential oil as the basic component, it increased $\mathrm{pH}$ and lowered $\mathrm{CO}_{2}$ amount and mold numbers. Studies concerning rumen fermentation reported that oregano essential oil showed an increasing effect on rumen pH (Soycan-Önenç, 2008).

For ESOM, the lowest value was found in CIN and the highest was found in CON. ME content calculated with the help of this data was determined to be the lowest in CIN (ME ESOM: $\left._{1,279} \mathrm{kcal} / \mathrm{kg} \mathrm{DM}\right)$. However, when the calculation was performed according to ADL amounts, the highest ME content was seen in CIN (ME $\mathrm{ADL}_{\mathrm{AD}}: 2031 \mathrm{kcal} / \mathrm{kg}$ DM). OA, ORE, CIN, and ORECIN which were added into field pea silages affected the crude nutrient matter contents differently. But the results of ME values of every feed showed great variation depending on regression equation calculations. On the other hand, in vitro ME values of field pea silages were estimated at different levels depending on different regression equations.

\section{IMPLICATIONS}

Cinnamon decreased $\mathrm{AA}$ and $\mathrm{NH}_{3}-\mathrm{N}$ loses at the end of 60 days silage. However, CP, ADF, and cellulose were increased, while ADL and hemicellulose decreased with the addition of cinnamon oil. Yeasts were not detected in any treatments, including the control, after 7 days of air exposure. Furthermore, cinnamon decreased the $\mathrm{CO}_{2}$ amount and inhibited the formation mold in the aerobic period. Oregano did not show a similar effect, but when it was used with cinnamon, it showed synergic effect on AA and during aerobic period, also it had an antagonistic effect on mold formation and DM loses. It was found in this study that cinnamon can be an alternative to organic acids.

Evaluation of the results was difficult since field peas are difficult to ensilage and this work is the one of the first studies using cinnamon and oregano as a silage additives. However, the results offer an important contribution to the literature as a pioneering study that will hopefully lead to more detailed future studies.

\section{CONFLICT OF INTEREST}

We certify that there is no conflict of interest with any financial organization regarding the material discussed in the manuscript. 


\section{ACKNOWLEDGMENTS}

This study was funded by NKUBAP (University of Namık Kemal Scientific Research Project) within the framework of NKUBAP.00.24.AR.11.04.

\section{REFERENCES}

Anonymous. 1986. The Analysis of Agricultural Material. Reference Book 427. HMSO, London, UK. 428 p.

Anonymous. 1991. Animal feeds-determination of metabolizable energy (chemical method). Turkish Standards Institute (TS9610) Ankara, Turkey. pp. 1-3.

Arslan, B., E. Ateş, and L. Coşkuntuna. 2012. Forage yıeld and some quality properties of safflower (Carthamus tinctorlus L.) - fodder pea (Plsum arvense L.) mixtures, as affected by sowing rates in thrace region, Turkey. Rom. Agric. Res. 29:255-260.

Ateş, E., L. Coşkuntuna, and A. S. Tekeli. 2010. The amino acid and fiber contents of four different annual forage legumes at full-bloom stage. Cuba. J. Agric. Sci. 44:73-78.

AOAC. 1990. Protein (crude) in animal feed, combustion method 990.03. In: Official Methods of Analysis. 15th edn. Association of Official Analytical Chemistry, Arlington, VA, USA. pp. 18-19.

Ashbell, G., Z. G. Weinberg, A. Azrieli, Y. Hen, and B. Horev. 1991. A simple system study the aerobic deterioration of silages. Can. Agric. Eng. 33:391-393.

Barker, S. B. and W. H. Summerson. 1941. The colorimetric determination of lactic acid in biological material. J. Biol. Chem. 138:535-554.

Bolsen, K. K., G. Ashbell, and Z. G. Weinberg. 1996. Silage fermentation and silage additives. Feed conservation laboratory, Agricultural Research Organization, The Volcani Center, Bet Dagan, Israel.

Burt, S. 2004. Essential oils: their antibacterial properties and potential applications in foods-a review. Int. J. Food Microbiol. 94:223-253.

Ceylan, A. 1996. Medicinal Plants II (Publication No.: 481). Ege Üniversity Ziraat Fakültesi, İzmir, Turkey.

Efe, E., Y. Bek, and M. Şahin. 2000. Statistical methods with solutions in SPSS (Publication No.: 73). Kahramanmaraş Sütçü İmam University, Kahramanmaras, Turkey.

Fernandes, G. M., R. A. Possenti, W. T. de Mattos, E. A. Schammass, and E. F. Junior. 2013. In situ degradability and selected ruminal constituents of sheep fed with peanut forage hay. Arch. Anim. Nutr. 67:393-405.

Filya, I. 2000. New developments in silage quality improvement. In: Proceedings of International Animal Nutrition Congress, Isparta, Turkey. September 4-6, 2000. pp. 243-250.

Filya, I. 2003. The effect of Lactobacillus buchneri and Lactobacillus plantarum on the fermentation, aerobic stability, and ruminal degradability of low dry matter corn and sorghum silages. J. Dairy Sci. 86:3575-3581.

Gallucci, M. N., M. Oliva, C. Casero, J. Dambolena, A. Luna, J. Zygadlo, and M. Demo. 2009. Antimicrobial combined action of terpenes against the food-borne microorganisms Escherichia coli, Staphylococcus aureus and Bacillus cereus. Flavour Fragr. J. 24:348-354.

Henderson, N. 1993. Silage additives. Anim. Feed Sci. Tech. 45:35-56

Jeroch, H., W. Drochner, and O. Simon. 1999. Nutrition of Farm Livestock. Ulmer, Stuttgart, Germany. 161 p.

Kirchgessner, M., R. J. Kellner, F. X. Roth, and K. Ranfft. 1977. Estimation of the feed values with crude fiber and cell wall fractions determined by detergents analyses. Landwirtsch. Forsch. 30:245-250.

Kirchgessner, M. and R. J. Kellner. 1981. Estimation of feed values of feed values of forages with cellulase method. Landwirtsch. Forsch. 34:276-281.

Kurtoğlu, V. 2011. Silage and Silage Additives. Aybil Publishing. Konya. Turkey. $356 \mathrm{p}$.

McDonald, P., A. R. Henderson, and S. J. Heron. 1991. The biochemistry of silage. 2nd edn. Chalcombe, Marlow, England. $340 \mathrm{p}$.

Nadeau, E. M. G., D. R. Buxton, J. R. Russell, M. J. Allison, and J. W. Young. 2000. Enzyme, bacterial inoculant, and formic acid effects on silage composition of orchardgrass and alfalfa. J. Dairy Sci. 83:1487-1502.

Naumann, C. and R. Bassler. 1993. Die Chemische Untersuchung von Futtermitteln. Methodenbuch Band III. VDLUFA-Verlag, Darmstadt, Germany.

Nguefack, J., J. B. Lekagne Dongmo, C. D. Dakole, V. Leth, H. F. Vismer, J. Torp, E. F. N. Guemdjom, M. Mbeffo, O. Tamgue, D. Fotio, P. H. Amvam Zollo, and A. E. Nkengfack. 2009. Food preservative potential of essential oils and fractions from Cymbopogon Citratus, Ocimum Gratissimum and Thymus Vulgaris against mycotoxigenic fungi. Int. J. Food Microbiol. 131:151-156.

Playne, M. J. and P. Mc Donald. 1966. The buffering constituent of herbage and of silage. J. Sci. Food Agric. 17:264-268.

Rondahl, T., J. Bertilsson, and K. Martinsson. 2011. Effects of maturity stage, wilting and acid treatment on crude protein fractions and chemical composition of whole crop pea silages (Pisum sativum L.). Anim. Feed Sci. Tech. 163:11-19.

Seale, D. R., G. Pahlow, S. F. Spoelstra, S. Lindgren, F. Dellaglio, and J. F. Lowe. 1990. Methods for the microbiological analysis of silage. In: Proceeding of The Eurobac Conference, Uppsala, Sweden. 147 p.

Soycan-Önenç, S. 2008. The effects of some aromatic plants on in vitro rumen fermentation. Ph.D. Thesis, Animal Science Agean University, Graduate School of Natural and Applied Science, İzmir, Turkey.

Van Soest, P. J., J. B. Robertson, and B. A. Lewis. 1991. Methods for dietary fibre, neutral detergent fiber and non-starch polysaccharides in relation to animal nutrition. J. Dairy Sci. 74:8583-3597.

Weissbach, F., L. Schmidt, and E. Hein. 1974. Method of anticipation of the run of fermentation in silage making, based on the chemical composition of gren fodder (Vol. III, Part II). In: Proceeding of 12th International Grassland Congress, Moskow, Rusia. pp. 663-673. 